jednokrotnie przemyślenia Ojców Kościoła i odpowiada na ponadczasowe pytania nurtujące człowieka każdej epoki. Książka kard. T. Špidlíka jest więc godna polecenia dla wszystkich, którzy pragną wybrać dla siebie drogocenne klejnoty spośród Perełek Ojców Kościoła i z pomocą tych słów, na wzór wczesnochrześcijańskich Ojców Pustyni, pogłębiać własną wiarę i życie duchowe.

Józef Trzebuniak SVD - Lublin, KUL

\title{
AELRED Z RIEVAULX, $O$ duszy, thum. i przypisy Magdalena Czubak, Kęty 2009, Wydawnictwo Marek Derewiecki, ss. 104.
}

Wydawnictwo naukowe Marka Derewieckiego, dawniej zwane „Antyk”, opublikowało kolejną już trzecią pozycję poświęconą postaci słynnego, dwunastowiecznego opata z cysterskiego klasztoru angielskiego Rievaulx (1110-1167). Do niedawna jeszcze ta mało komu znana postać stała się dziś w naszych czasach prawdziwym odkryciem i punktem zainteresowań wielu badaczy oraz zwykłych czytelników. Sama jego postać zasługuje już bez wątpienia na to zainteresowanie, ale przede wszystkim podejmowana przez niego tematyka chrześcijańskiej przyjaźni, o której napisał specjalny traktat teologiczny, wyjątkowy w tamtych czasach, sprawia, że ludzie chca go dziś znać i czytać. W Polsce, po kilku artykułach (por. np. specjalny tom czasopisma „Cistercium Mater Nostra” 2:2008, nr 1, o przewodnim tytule: Aelred z Rievaulx - myśl i czasy), jedynie Wydawnictwo „Antyk”, zaczęło od niedawna publikować jego dzieła i książki jemu poświęcone. Trudność bierze się stąd, że oryginalne dzieła Aelreda były napisane w kościelnej, średniowiecznej łacinie, stąd ich przekład wymaga wykwalifikowanych tłumaczy języka łacińskiego oraz znawców kultury średniowiecznej. W miarę upowszechniania się studiów z dziedziny mediewistyki wzrasta również ilość takich badaczy w Polsce. Oprócz najbardziej znanego traktatu o przyjaźni (Aelred z Rievaulx, Przyjaźn duchowa, tłum. M. Wylęgała, Kęty 2004), wspomniane Wydawnictwo opublikowało również książkę Ryszarda Gronia, opisującego jałową 25-letnią dyskusję, jaka toczyła się w środowisku amerykańskim, na temat orientacji seksualnej Aelreda (Spór o Aelreda. W poszukiwaniu prawdziwego oblicza Aelreda z Rievaulx, Kęty 2005). Niniejsza pozycja jest zatem drugim dziełem Aelreda i trzecią książką w Polsce jemu poświęconą.

Tłumaczka, Magdalena Czubak, jest absolwentką Uniwersytetu Warszawskiego, na którym obroniła dysertację doktorską z tematyki Aelreda. Wcześniej, jak dowiadujemy się z jej bibliografii, pracowała również nad antropologią i koncepcją przyjaźni u Aelreda. Więc Aelred z całym jego środowiskiem kulturowym jest jej dobrze znany. Autorka podjęła się wyzwania przetłumaczenia aelrediańskiego utworu $O$ duszy (Dialogus de anima), a za podstawę posłużyło jej krytyczne wydanie dzieł Aelreda: Aelredi Rievallensis, Opera omnia - opera ascetica, ed. A. Hoste - C.H. Talbot, Corpus Cristianorum. Continuatio Mediaevalis 1, Turnholti 1971, gdzie utwór $O$ duszy znajduje się na s. 685-754. 
Aelred jest znany zwłaszcza ze swojej działalności polityczno-pastoralnej. Jeden z pierwszych klasztorów cysterskich w Anglii (założony w 1132), którego był opatem (1147-1167), pod jego zarządem, stał się znaczącym ośrodkiem religijno-kulturowym. Oprócz tej działalności, napisał kilka utworów historycznych i duchowych, z których największy rozgłos przyniosły mu traktaty duchowe: Zwierciadło miłości (Speculum caritatis) (1142-1143) i O przyjaźni duchowej (De spiritali amicitia) (1147/1165). Wszystkie utwory były pisane pod wyraźnym wpływem tradycji augustyńskiej, królującej w owym czasie powszechnie pod szyldem tzw. teologii monastycznej, uprawianej w klasztorach.

De anima uważa się powszechnie za ostatni utwór Aelreda powstały u schyłku jego życia, tj. w latach 1163-1166. W opinii jego biografa, W. Daniela, jak również innych badaczy którzy poszli za jego wskazówką, jest on niedokończony z powodu śmierci autora, na co miałyby wskazywać również ostatnie dwa wersy utworu. Uważna lektura ostatnich paragrafów i osiagnnięty niewątpliwie punkt kulminacyjny, mogąjednak wskazywać na to, iż opat ukończył swoje dzieło przed śmiercią. Ilość zachowanych rękopisów (2) pochodzących z XII w., i tylko z Anglii, świadczy o jego małej popularności i braku wpływu na pozostałe opactwa cysterskie w Europie. Problematyka duszy, zwłaszcza teoretyczne dywagacje na jej temat, nie znalazły bowiem takiego zainteresowania w bardziej pragmatycznej teologii monastycznej, jaką wówczas uprawiano, aczkolwiek rozważania tego typu były potrzebne, ze wzgędu na ukazanie mechanizmu działania łaski Bożej w człowieku.

Podobnie jak najpopularniejsze dzieło Aelreda - O przyjaźni duchowej, utwór ten, zgodnie zresztą z tytułem, ma formę dialogu, jaką prowadzi sam Aelred z jednym $\mathrm{z}$ zakonników - Janem. Na tle prostej fabuły przedstawia $\mathrm{w}$ trzech ksieggach (dialogach) problematykę duszy. Najpierw omawia naturę duszy, jej pochodzenie od Boga i nieśmiertelny charakter duchowy oraz jej relacje do ciała (1); następnie, rolę nierozłącznych trzech władz duszy: pamięci, rozumu i woli, które stanowią samą substancję duszy, dzięki czemu też wykonuje ona swoje funkcje: wyobraźni, odczuwania, myślenia i wolnych wyborów (2); wreszcie, stan duszy po śmierci, tzn. po jej odzieleniu od ciała (3). Rozważania Aelreda na tle myśli augustyńskiej są czasem oryginalne, i nieraz włączają się do ogólnej dyskusji, jaką ówczesnie prowadzono, na temat natury duszy ludzkiej, jej związku z ciałem i jej statusem poza nim.

Lektura traktatu Aelreda w thumaczeniu Magdaleny Czubak jest zwięzła i w miare łatwa, na tyle na ile pozwala na to sama tematyka. Zahacza bowiem ona często o teoretyczne dysputy, nie mające większego zastosowania w życiu, aczkolwiek ważne dla ówczesnej teologii. Tłumaczka znakomicie dała sobie radę z nimi, i na ich tle zdaje się być specjalistką w swojej dziedzinie, pokonując nie tylko językowo-gramatyczne łamigłówki łaciny kościelnej XII wieku, ale również orientując się w kulturowo-historycznych szczegółach i niuansach. Zaskakuje bogactwem źródłowym ukazanym w przypisach, oraz szczegółową bibliografią, wskazującą na kompetencję i dobre rozeznanie. Należy pogratulować tłumaczce 
wspaniałego dzieła i życzyć dalszych sukcesów w tłumaczeniu kolejnych dzieł Aelreda, by go jak najbardziej rozpowszechnić w środowisku polskim.

ks. Ryszard Groń - Wrocław, PWT 